\title{
Groundwater Vulnerability Assessment for the Corridor Wellfield Using DRASTIC and Modified DRASTIC Models: A Case Study of Eastern Jordan
}

\author{
Ibraheem Hamdan ${ }^{*}$, Abdulla Al-Rawabdeh ${ }^{2,3}$, Mu'ayyad Al Hseinat ${ }^{4}$ \\ ${ }^{1}$ Institute of Earth and Environmental Sciences, Al al-Bayt University, Mafraq, Jordan \\ ${ }^{2}$ Department of Earth and Environmental Sciences, Yarmouk University, Irbid, Jordan \\ ${ }^{3}$ Applied Geoinformatics Laboratory, Yarmouk University, Irbid, Jordan \\ ${ }^{4}$ Department of Geology, The University of Jordan, Amman, Jordan \\ Email: *ibraheem.hamdan@aabu.edu.jo, abd_rawabdeh@yu.edu.jo,m.hseinat@ju.edu.jo
}

How to cite this paper: Hamdan, I., Al-Rawabdeh, A. and Al Hseinat, M. (2020) Groundwater Vulnerability Assessment for the Corridor Wellfield Using DRASTIC and Modified DRASTIC Models: A Case Study of Eastern Jordan. Open Journal of Geology, 10, 991-1008.

https://doi.org/10.4236/ojg.2020.1010046

Received: September 23, 2020

Accepted: October 6, 2020

Published: October 30, 2020

Copyright $\odot 2020$ by author(s) and Scientific Research Publishing Inc. This work is licensed under the Creative Commons Attribution International License (CC BY 4.0).

http://creativecommons.org/licenses/by/4.0/

\begin{abstract}
Groundwater vulnerability maps were created for the Corridor wellfield $\left(\sim 300 \mathrm{~km}^{2}\right)$ in the eastern Jordan using the DRASTIC and modified DRASTIC groundwater vulnerability assessment models. The study area is considered as one of the most important well fields therein providing partially three governorates with the needed drinking water. Detailed geological and hydrogeological parameters as well as the land-use map of the area were obtained from various sources to utilize both models. ArcGIS software was used for calculations and maps preparation. As a result, the generic DRASTIC vulnerability index ranges between 109 and 168. Thus, two vulnerability classes were observed, moderate (9.9\%) and high (90.1\%) vulnerability classes. On the other hand, the modified DRASTIC model (risk map) is taking into account the land-use map classes in the study area. The output risk map reveals two main classes, the moderate and high-risk areas. The moderate-risk areas occupy $9.3 \%$ of the total volume of the study area while the high-risk areas are $90.7 \%$. Due to the high depth to groundwater within the area (between $90 \mathrm{~m}$ and $390 \mathrm{~m}$ ), the depth to groundwater intervals was modified in the model to become more comfortable with the situation in Jordan. The high percentage of the high vulnerable areas against pollutants reflects the need to do more investigation for the studied area.
\end{abstract}

\section{Keywords}

DRASTIC, Risk Map, Groundwater Vulnerability, Corridor Wellfield, Jordan

${ }^{*}$ Corresponding author. 


\section{Introduction}

In Jordan, the extremely limited water resources make water scarcity as one of the major problems in the country. More than $90 \%$ of the country can be described as an arid region and receives less than $200 \mathrm{~mm} /$ year [1]. The groundwater basins in Jordan suffer from over-pumping, which exceeds the natural replenishment of the groundwater. For example, in 2017/2018 the total abstraction from groundwater basins was around $641 \mathrm{MCM}$ and even though $418 \mathrm{MCM}$ is considered a safe yield pumping rate from these groundwater basins [2]. In addition to water scarcity, some of the water resources in Jordan are suffering from pollution as a result of the random use of fertilizers and pesticides, illegal dumping of solid and liquid wastes, design problems in landfills, and non-effective wastewater treatments. All these pollution sources put groundwater in danger. Different measures must be taken into account to protect Jordan's groundwater (i.e. groundwater vulnerability maps).

The term groundwater vulnerability assessment against pollutants was introduced by Margat [3]. The US EPA defines groundwater vulnerability as the relative ease with which contaminants applied on/or near the land's surface can migrate into the aquifer of interest under a given set of agronomic management practices, pesticide characteristics, and hydrogeological sensitivity conditions.

A groundwater vulnerability assessment was derived from the assumption that the physical environment may provide some degree of protection to groundwater against natural and human impacts, especially with regards to the pollutants entering the subsurface zone (e.g., [4] [5] [6]. However, there is no specific and universal groundwater vulnerability method [7]. Mimi et al. [7] classified the groundwater vulnerability assessment methods into three main groups: 1) process-based simulation assessment, 2) statistical assessment, and 3) overlay and index assessment method.

Several groundwater vulnerability methods were developed during the past decades, such as the DRASTIC [8], GLA [9], SINTACS [10], EPIK [11], PI [12], and COP [13]. Goldscheider [14] divides the groundwater vulnerability assessment maps into two main types: the intrinsic and specific maps. The intrinsic groundwater vulnerability map describes the aquifer and its vulnerability against pollutants based on its natural characteristics (the geological and hydrogeological parameters) while the specific vulnerability assessment describes the groundwater vulnerability against pollutants by taking the natural properties of the aquifer together with the contaminant properties itself. Goldscheider [14] considered the groundwater vulnerability maps of both types (intrinsic and specific) as important and valuable tools for monitoring and protecting groundwater resources from pollution.

In this study, a groundwater vulnerability map against the pollution and risk map is prepared using the DRASTIC and modified DRASTIC index models for the Corridor wellfield area to the east of Mafraq city (Figure 1). This area is of high interest as one of the most important wellfields in the east of Jordan. The 


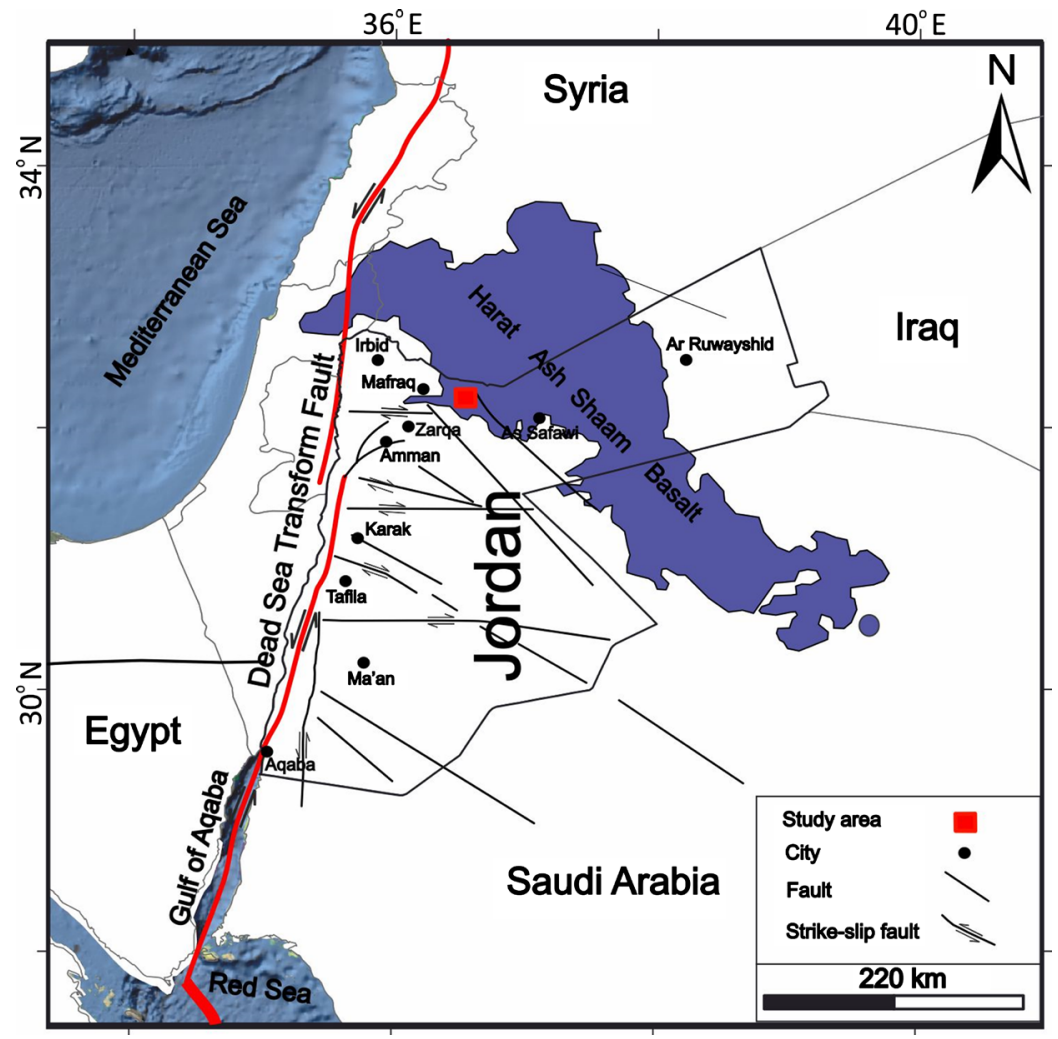

Figure 1. Map of Jordan shows the location of the Corridor wellfield east of Mafraq city (modified from [15] and references therein).

abstracted water from the wellfield is divided between the city of Zarqa on one side and Irbid and Mafraq (through Zaatari pumping station) on the other side. Groundwater vulnerability maps for the main drinking water resources are important tools, particularly for the decision-makers to protect the limited water resources from pollutants.

The main purpose of this study is to evaluate the vulnerability of the Corridor wellfield using the DRASTIC index model and the modified DRASTIC index model (risk map). DRASTIC index parameters and geographic information system (GIS) techniques are combined and examined to provide an effective management tool to groundwater quality and vulnerability. This work will support decision-makers by providing efficient information for the development of strategies for land-use management of the catchment area. This study will also identify areas highly susceptible to the contamination that will benefit from further conservation measures.

\section{Study Area Description}

The study area, the Corridor wellfield, is $\sim 300 \mathrm{~km}^{2}$ and located in the eastern part of Mafraq city, about $90 \mathrm{~km}$ northeast of the city of Amman (Figure 1). The Corridor wellfield partially supplies three governorates with drinking water (Amman, Zarqa, and Irbid governorates). For the year 2016, the mean pumping rate from the wellfield was 5.2 MCM [16]. The study area has a gentle slope to- 
pography with little increase in elevation $(600 \mathrm{~m}$ in the southwest to $915 \mathrm{~m}$ in the northeast). In the study area, the precipitation decreases from west to east ranging between 100 and $150 \mathrm{~mm} / \mathrm{a}$ [17].

The Corridor wellfield was previously mapped by the Ministry of Energy and Natural Resources, as part of the 1:50,000 National Mapping Project. A large database, including information about geological units and structural features, such as faults, was produced from four hard copy geological map sheets in the form of GIS thematic layers enabling interpretation and analysis: Hababiyya sheet No. 3354-II [18], Qasr al Hallabat sheet No. 3254-II [19], Umm el Quttein sheet No. 3354-IV [20], and Umm el Jemal sheet No. 3254-I [21]. These maps were converted into a digital format by using the scanner, uploaded to the GIS environment, and then geo-referenced. The geological boundaries and major features were manually digitized. This information was then integrated into one map includes the geological units and the main structural elements within the study area (Figure $2(\mathrm{a})$ ).

The outcropping geological map in Figure 2(a) shows that the study area is covered mainly by basaltic rocks, which belong to the Harat Ash Shaam Basaltic Super Group of Neogene-Quaternary age. The directions of the basaltic flow are approximately from north to south. The rocks comprise a classical continental basaltic flow of the alkali olivine basalt, which are derived from an upper mantle source by a variable degree of partial melting with minor secondary differentiation.

In the study area, the basaltic rocks belong to different extrusive sources, such as fissure eruption, feeder dykes, volcanic vent, and as flows from outside the area. The Abed Olivine basalt formation (Late Miocene) represents the oldest volcanic rocks therein [22]. It is up to $30 \mathrm{~m}$ thick and composed of massive basaltic flow, blocky, grey, holocrystalline, fine-grained, porphyritic texture with olivine altered to iddingsite.

The Fahda vesicular basalt formation (Pliocene-Pleistocene) is the youngest basaltic rocks present in the study area covering broad areas and extending from north to south (Figure 2(a)). This formation is 5 - $35 \mathrm{~m}$ thick and consists of individual and massive columnar basalt (up to $2 \mathrm{~m}$ long) forming small hills and rough surfaces [22]. It is characterized by dark color and slightly weathered linear pressure ridge.

Two main basaltic dykes are present in the study area (Figure 2(a)). For example, the Khureiriba dyke is the main basaltic dyke present in the study area, trending NW-SE and forming isolated hill and linear ridge [22]. The Pleistocene to recent deposits cover only part of the basaltic rocks due to the high erosional rate [22]. These deposits are composed of alluvium and wadi sediments that are poorly sorted, angular to sub-angular gavels with pebbles and boulders of basalt, limestone and fragments of chert with silt and clay [22].

The Alluvium Mudflats are mainly consisting of soft clay, slit and some sand with scattered boulders of basalt. Soil, red and yellow brown, covers areas throughout the basaltic flows (at the surface or as a thin veneer occurs between different basaltic flows in vertical position). 

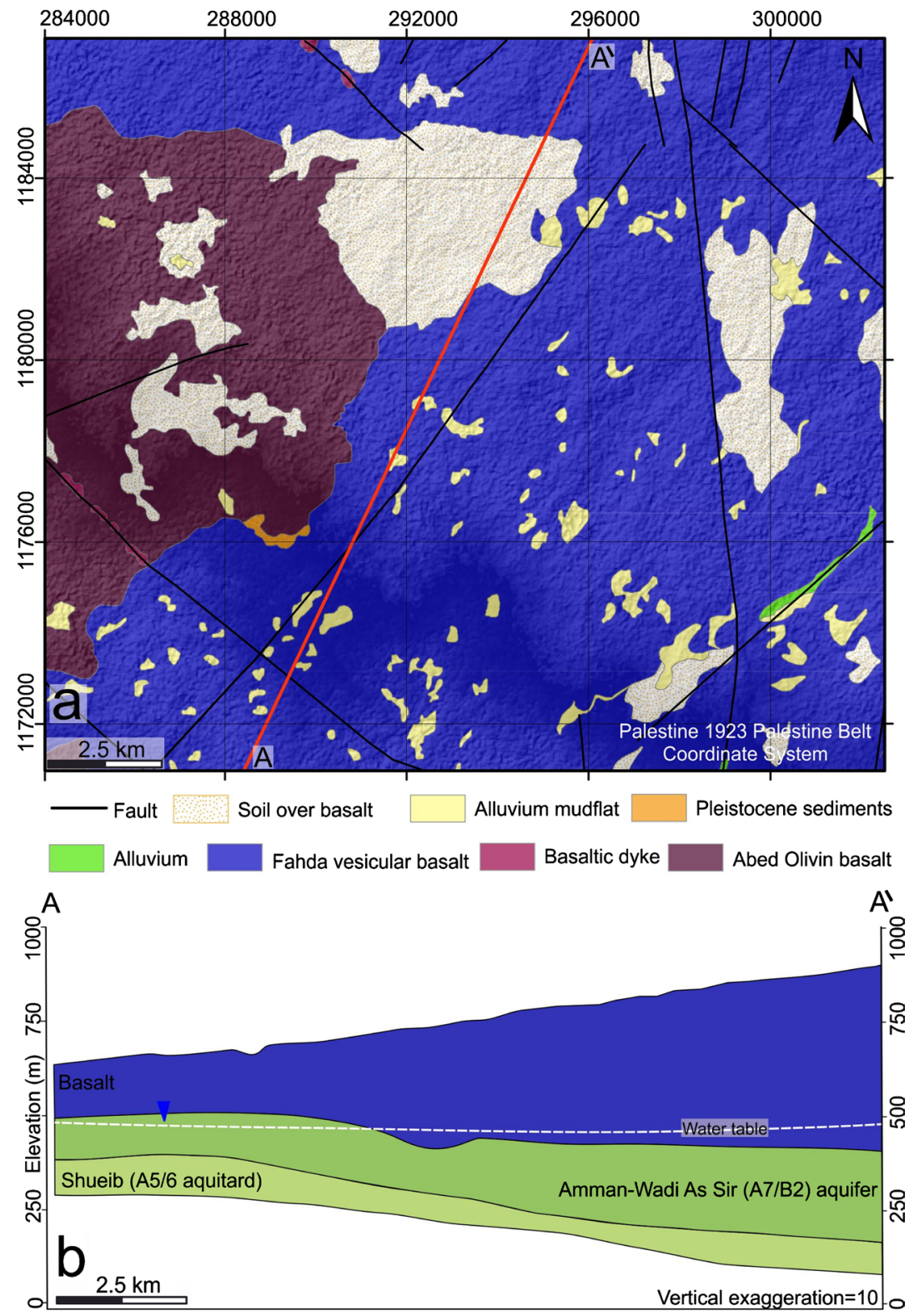

Figure 2. (a) A generalized map of geological units and the main structural elements of the study area (based on [18] [20] [19] [21]). The red line shows the location of the cross-section. (b) SSW-NNE-trending geological cross-section of the study area (drawn based on [23] data).

The structural map of the study area shows two main fault trends (NW-SE, NNE-SSW) and a minor trend of N-S [17]. The NW-SE-trending faults follow the general trend of the basalt extrusion. The NNE-SSW-trending faults follow the direction of the Dead Sea Transform Fault (Figure 2(a)).

Two major hydrogeological units dominate the aquifer system of the area: the limestone sequences of the Upper Cretaceous rocks (upper Ajlun (A7), Lower Balqa (B2) groups), and the volcanic rocks (basalt) from the Neogene and Quaternary ages (Figure 2(b)). The Wadi As Sir Limestone Formation (A7 from Ajlun Group), together with the Amman Silicified Limestone Formation (B2 
from Balqa Group) is considered to be the main aquifer (A7/B2) in the study area. It consists of well-bedded thin to massive limestone, dolomitic limestone, and dolomite with chert and not outcropping in the study area due to the thick basaltic cover within the area.

The basaltic rocks within the study area reach a total thickness between $100 \mathrm{~m}$ in the southwestern part and $500 \mathrm{~m}$ in the northeastern part [23]. The thickness of the Amman Wadi As Sir Formation (A7/B2) ranges between $\sim 100 \mathrm{~m}$ (in the southwestern and central parts) and $\sim 200 \mathrm{~m}$ (in the northeastern part of the area), to reaches the maximum thickness $(\sim 300 \mathrm{~m})$ in the eastern part of the study area [23].

Altfelder et al. [24] studied both the basaltic and the Amman-Wadi as Sir Limestone aquifers within the Corridor wellfield and found that they are hydraulically connected. The thickness of the saturated zone of the A7/B2 aquifer ranges between $\sim 75 \mathrm{~m}$ in the western part and $\sim 500 \mathrm{~m}$ in the eastern part of the study area [25].

\section{Methodology}

The DRASTIC vulnerability model is considered as one of the oldest and most common overlay index methods worldwide for identifying the regions that are affected by contaminants. It was first introduced by Aller et al. [8] and developed to assess relative groundwater pollution susceptibility using weights and rates for multiple hydrological and hydrogeological parameters. Aller et al. [8] calculated the DRASTIC index using Equation (1) with seven hydrogeological parameters including the depth to water, net recharge, aquifer media, soil, topography, the impact of the vadose zone, and hydraulic conductivity. Each parameter has a specific weight and a group of rates for each weight category.

$$
\begin{aligned}
\text { DRASTIC index }= & \mathrm{Dr} * \mathrm{Dw}+\mathrm{Rr}^{*} \mathrm{Rw}+\mathrm{Ar} * \mathrm{Aw}+\mathrm{Sr} * \mathrm{Sw} \\
& +\mathrm{Tr} * \mathrm{Tw}+\mathrm{Ir}^{*} \mathrm{Iw}+\mathrm{Cr} * \mathrm{Cw}
\end{aligned}
$$

where $\mathrm{D}$ is depth to water, $\mathrm{R}$ is net recharge, $\mathrm{A}$ is aquifer media, $\mathrm{S}$ is soil media, $\mathrm{T}$ is topography, $\mathrm{I}$ is impact of vadose zone, and $\mathrm{C}$ is hydraulic conductivity.

In the Equation (1) above, each parameter has different weight (w) ranging from 1 to 5 and different rates ( $r$ ) ranging from 1 to 10 (Table 1).

As mentioned earlier, groundwater levels in Jordan decreased dramatically due to the over-extraction where water abstraction exceeds its natural replenishment. It is well-known that the water table (depth to reach water) in Jordan is more than $200 \mathrm{~m}$ depth. Based on that, the "depth to groundwater" parameter was modified in this study to become more comfortable with the situation in Jordan.

The net recharge value was calculated based on the Equation (2) [27] [28]. Table 2 summarizes the factors for each parameter in the Equation (2) (Permeability, Precipitation, and Slope).

$$
\text { Recharge value }=\text { Slope } \%+\text { Rainfall }+ \text { Soil permeability }
$$

The modified DRASTIC vulnerability index map (Risk map) was calculated 
Table 1. The assigned DRASTIC index weight and rate for each hydrogeological parameter (modified after [8] [26]).

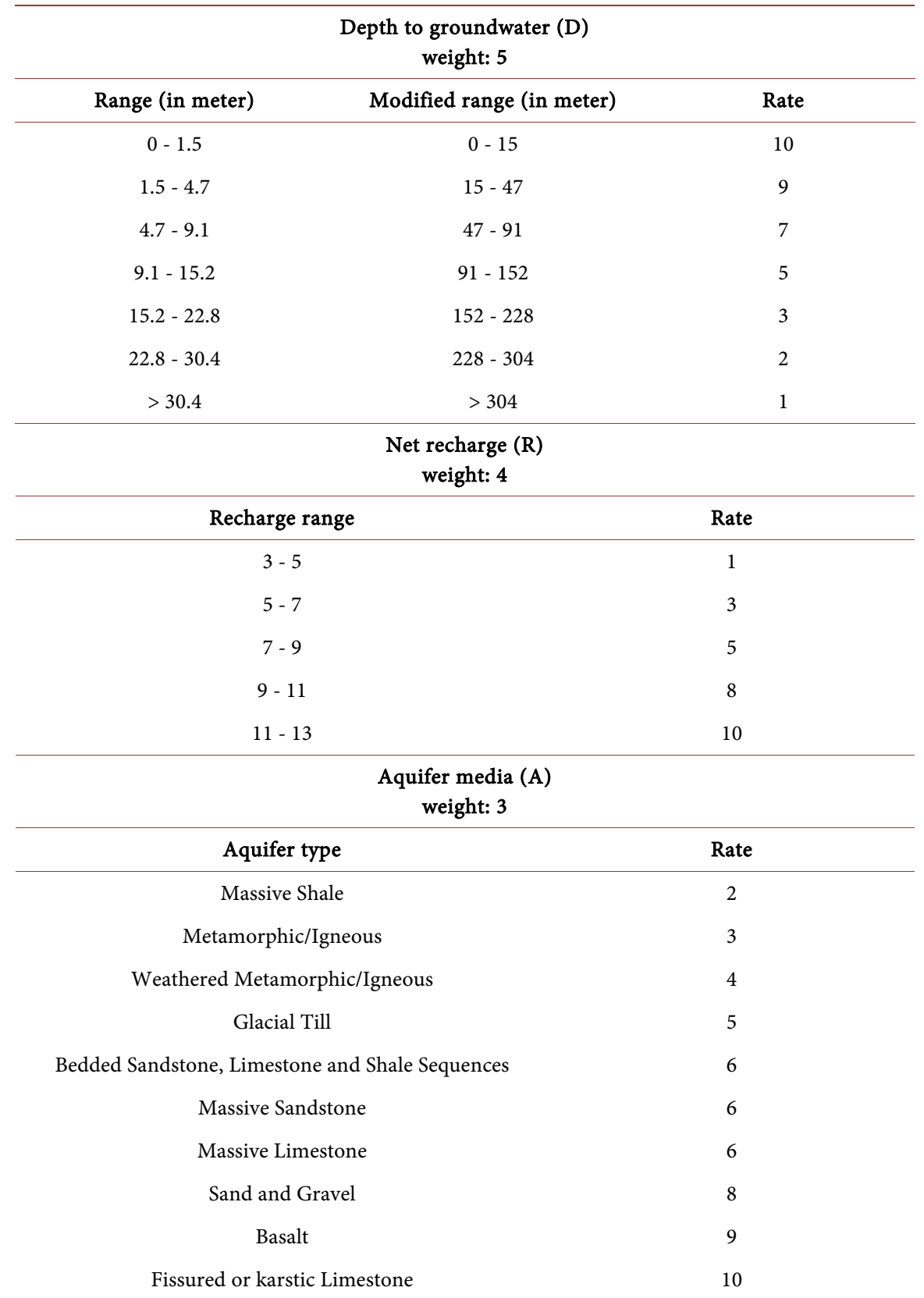

\begin{tabular}{cc}
\hline & $\begin{array}{c}\text { Soil media (S) } \\
\text { weight: } 2\end{array}$ \\
\hline Soil media & Rate \\
\hline Thin or Absent & 10 \\
Gravel & 10 \\
Sand & 9 \\
Peat & 8 \\
Shrinking and/or Aggregated Clay & 7 \\
Sandy Loam & 6 \\
\hline
\end{tabular}




\section{Continued}

\begin{tabular}{|c|c|}
\hline Loam & 5 \\
\hline Silty Loam & 4 \\
\hline Clay Loam & 3 \\
\hline Muck & 2 \\
\hline Non-shrinking and Non-aggregated Clay & 1 \\
\hline \multicolumn{2}{|c|}{$\begin{array}{c}\text { Topography (T) } \\
\text { weight: } 1\end{array}$} \\
\hline Slope (\%) & Rate \\
\hline $0-2$ & 10 \\
\hline $2-6$ & 9 \\
\hline $6-12$ & 5 \\
\hline $12-18$ & 3 \\
\hline$>18$ & 1 \\
\hline \multicolumn{2}{|c|}{$\begin{array}{l}\text { Impact of the vadose zone media (I) } \\
\text { weight: } 5\end{array}$} \\
\hline Media & Rate \\
\hline Confining Layer & 1 \\
\hline Silt/Clay & 3 \\
\hline Shale & 3 \\
\hline Limestone & 6 \\
\hline Sandstone & 6 \\
\hline Bedded Limestone, Sandstone, Shale & 6 \\
\hline Sand and Gravel with significant Silt and Clay & 6 \\
\hline Metamorphic/Igneous & 4 \\
\hline Sand and Gravel & 8 \\
\hline Basalt & 9 \\
\hline Fissured or karstic Limestone & 10 \\
\hline
\end{tabular}

Hydraulic Conductivity (C)

weight: 3

\begin{tabular}{cc} 
Range $(\mathrm{m} / \mathrm{s})$ & Rate \\
\hline $\begin{array}{c}4.716 \times 10^{-7}-4.716 \times 10^{-5} \\
4.716 \times 10^{-5}-1.41 \times 10^{-4}\end{array}$ & 1 \\
$1.41 \times 10^{-4}-3.3 \times 10^{-4}$ & 2 \\
$3.3 \times 10^{-4}-4.716 \times 10^{-4}$ & 4 \\
$4.716 \times 10^{-4}-9.43 \times 10^{-4}$ & 6 \\
$>9.43 \times 10^{-4}$ & 8 \\
Land-use (L) & 9 \\
Land-Use & weight: 5 \\
baricultural areas & Rate \\
urban areas & 5 \\
\hline
\end{tabular}


based on the following Equation (3) [28] [26]:

$$
\mathrm{MDi}=\mathrm{Di}+(\mathrm{Lr} * \mathrm{Lw})
$$

where (MDi) is the modified DRASTIC index, (Di) is the DRASTIC index vulnerability map, and $\mathrm{Lr}$ and Lw represent the rate and weight for land-use. Each land-use class has a specific rate (see Table 1) with a specific weight equal to 5 .

In order to apply the DRASTIC index model, different datasets in different formats are required. Therefore, the entire data were prepared and converted (if necessary) into raster data formats. A raster calculator in the ArcGIS software is utilized for the required equations and to calculate the final DRASTIC map. Table 3 summarizes the layers that were used to assess groundwater vulnerability map within the study area.

\section{Results and Discussion}

\subsection{DRASTIC Index Parameters}

In this study, the DRASTIC vulnerability assessment model was applied to produce a vulnerability map for the Corridor wellfield area, east of Mafraq city. This study was done based on an overlying method using GIS techniques taking assigned rates and weights for each parameter. It is well-known that the higher calculated vulnerability index means a greater potential for groundwater to be contaminated [32] [33].

Depth to groundwater is an important parameter because deeper water levels result in longer travel time. The presence of low permeability layers will also limit the travel of contaminants into an aquifer. The depth to groundwater rate

Table 2. The main factors used for calculating the net recharge [27] [28].

\begin{tabular}{cccccc}
\hline \multicolumn{2}{c}{ Permeability } & \multicolumn{2}{c}{ Rainfall } & \multicolumn{2}{c}{ Slope } \\
\hline Permeability & Factor & rainfall (mm/year) & Factor & Slope (\%) & Factor \\
\hline High & 6 & $>850$ & 4 & $<2$ & 4 \\
Moderate & 4 & $700-850$ & 3 & $2-10$ & 3 \\
Low & 2 & $500-700$ & 2 & $10-32$ & 2 \\
& & $<500$ & 1 & $>33$ & 1 \\
\hline
\end{tabular}

Table 3. Required data types and sources for the DRASTIC model.

\begin{tabular}{|c|c|}
\hline Layer & Sources \\
\hline Slope & $\begin{array}{c}\text { Derived based on ALOS PALSAR digital elevation model (12.5 m spatial } \\
\text { resolution) [29] }\end{array}$ \\
\hline Land-use & Digitized from Google Earth (C) \\
\hline Soil texture & Ministry of Agriculture [30] \\
\hline Geology & Ministry of energy and minerals resources (hard-copy sheet maps) \\
\hline Depth to groundwater & Ministry of water and irrigation [31] \\
\hline Precipitation & Ministry of water and irrigation (MWI; long duration isohyetal lines) \\
\hline
\end{tabular}


will be higher if the water table is shallow and closer to the surface. In general, the depth to groundwater within the study area is deep. It ranges between $90 \mathrm{~m}$ and $390 \mathrm{~m}$. Based on that, and in accordance with Table 1, Figure 3 represents the depth to groundwater index map ( $\left.\mathrm{Dr}{ }^{*} \mathrm{Dw}\right)$.

The recharge rate is controlling the amount of water that penetrates the ground surface and reaches the water table. It transports contaminants vertically to the water table and horizontally within the aquifer. It also controls the volume of the water available for dispersion and dilution of the contaminant in the vadose and saturated zones [27]. Three main parameters were used to calculate the net recharge value: slope, rainfall, and soil permeability. The calculated recharge value (based on Equation (2); Table 2) was then grouped into a range of values which was used in the calculation process of the DRASTIC vulnerability model. Figure 4 represents the calculated net recharge index map $\left(\mathrm{Rr}^{*} \mathrm{Rw}\right)$ within the study area.

Aquifer media and characteristics control the groundwater occurrence and its movement. As mentioned in the hydrogeological setting of the area, the aquifer media is limestone. According to Table 1 and the available data from the aquifer within the area, the rate was assigned equal to 10 for the entire study area.

Soil texture has a significant impact on the amount of recharge that can infiltrate the water table. The presence of fine-textured materials, such as silts and clays, can decrease the relative soil permeability and contaminants movement rates [34]. Based on the soil units and the geological setting of the study area,

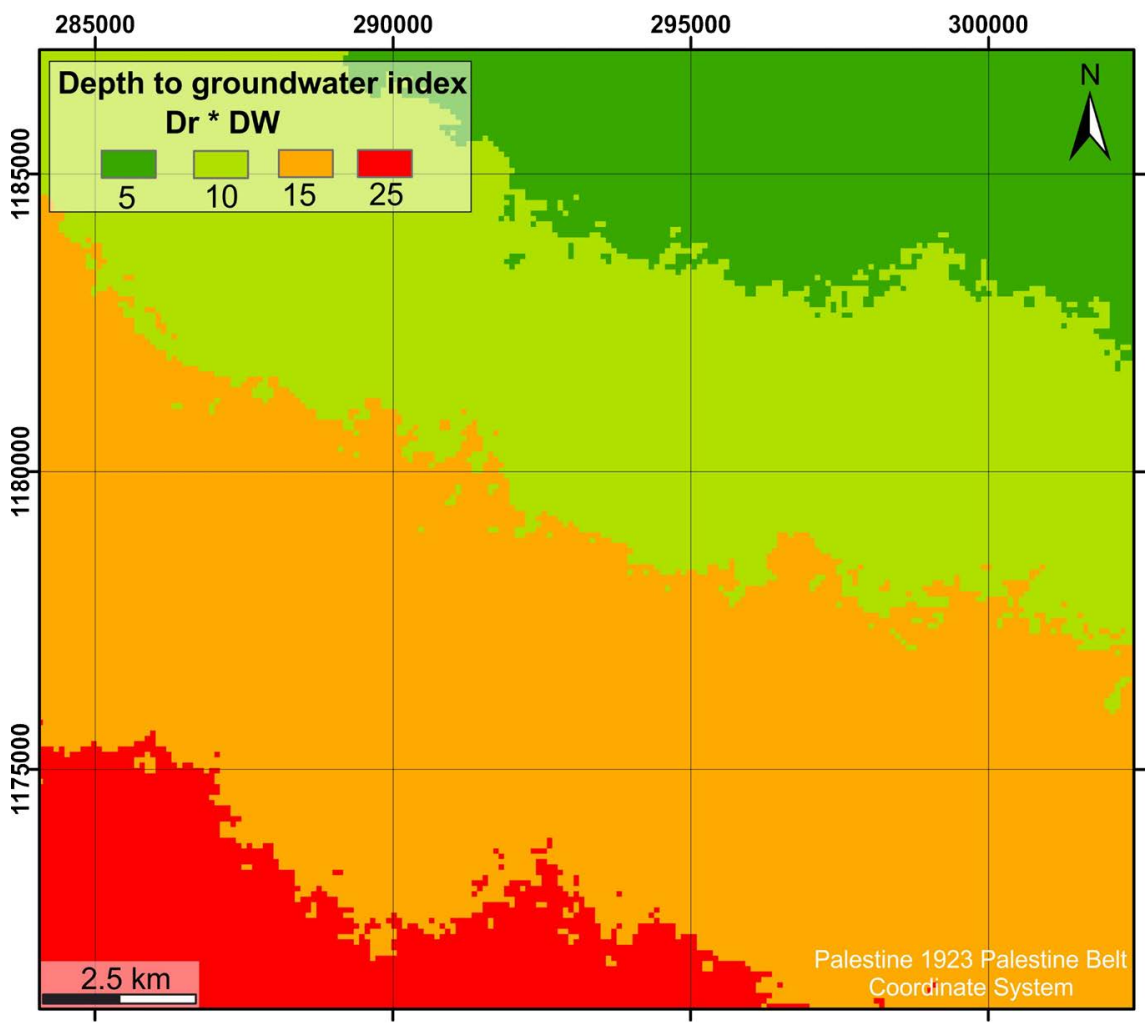

Figure 3. Depth to groundwater index map $\left(\mathrm{Dr}^{\star} \mathrm{Dw}\right)$ of the Corridor wellfield area. 


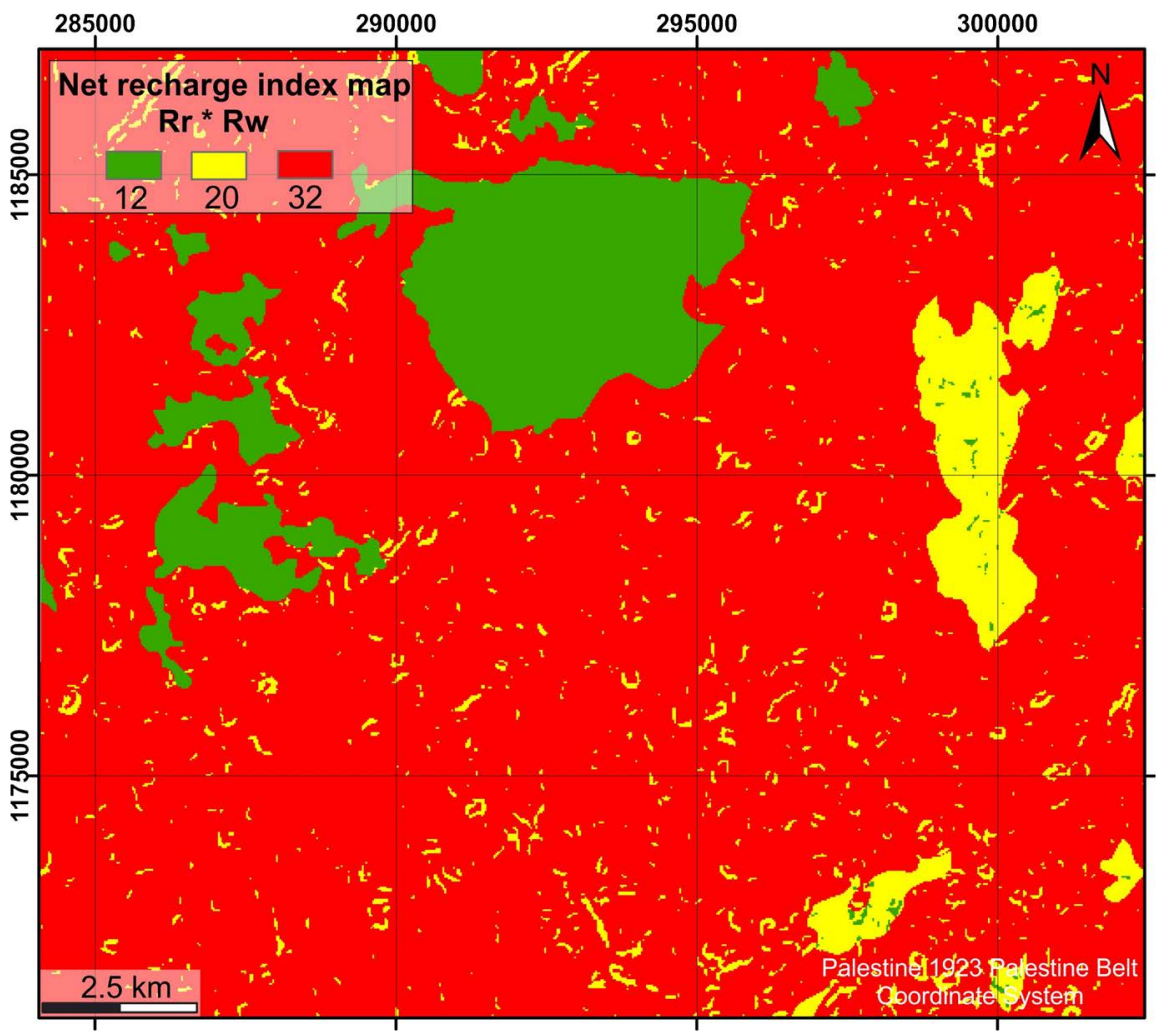

Figure 4. Net recharge index map $\left(\mathrm{Rr}^{\star} \mathrm{Rw}\right)$ of the Corridor wellfield area.

four main groups of soil textures were identified: thin or absent, silty clay, silty loam, and loam soil textures. Figure 5 represents the soil media index map ( $\mathrm{Sr}$ * $\mathrm{Sw})$ within the study area.

Topography represents a critical factor related to groundwater vulnerability maps as it helps to control pollutant runoff or retention on the surface. These mean areas with low steepness tend to retain water for longer; this allows a greater infiltration of recharge of water and a greater potential for contaminant migration [35]. The topography of the study area is a gentle slope. The slope in percentage ranged between $1 \%$ and $28 \%$. The slope percentage was classified according to Table 1. Figure 6 shows the topography index map of the study area $\left(\mathrm{Tr}{ }^{\star} \mathrm{Tw}\right)$.

According to [27] [34], the type of vadose zone media determines the attenuation characteristics of the materials above the water table (the soil and rock). Natural attenuation of pollutants concentration will occur during the pollutants passage in the unsaturated zone due to the physical and chemical interaction between the rock materials and the pollutants [36] [6]. Within the study area, basalt is the unsaturated zone. According to Table 1, the rate of the basalt is equal to 9 , and hence, the (Ir ${ }^{\star} \mathrm{Iw}$ ) equal to 45 was assigned for the entire study area.

In most vulnerability maps, hydraulic conductivity plays an important role since it is controlled by the amount and interconnection of void spaces within the aquifer that may occur due to the intergranular porosity, fracturing and/or 


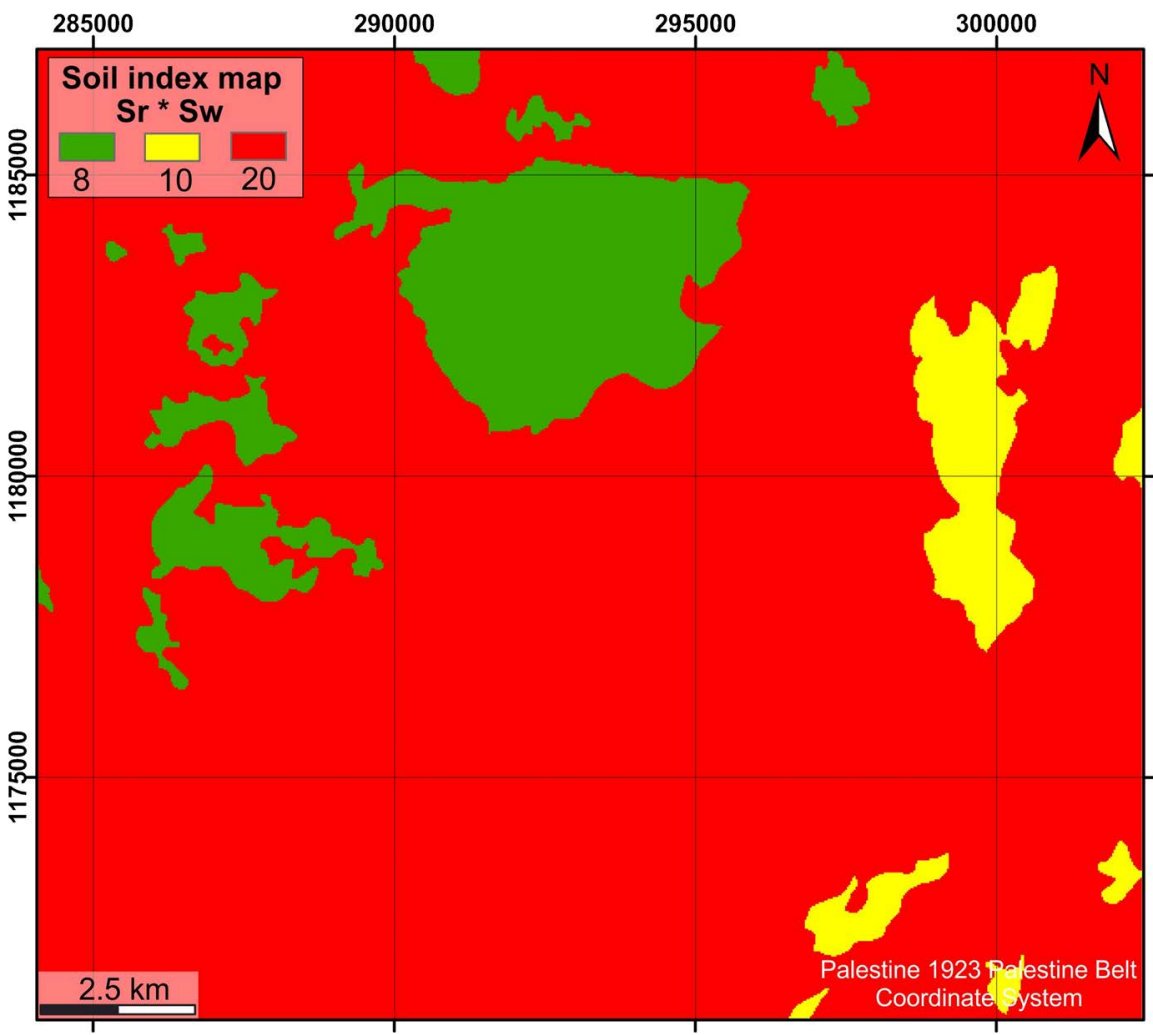

Figure 5. Soil media index map $\left(\mathrm{Sr}{ }^{\star} \mathrm{Sw}\right)$ of the Corridor wellfield area.

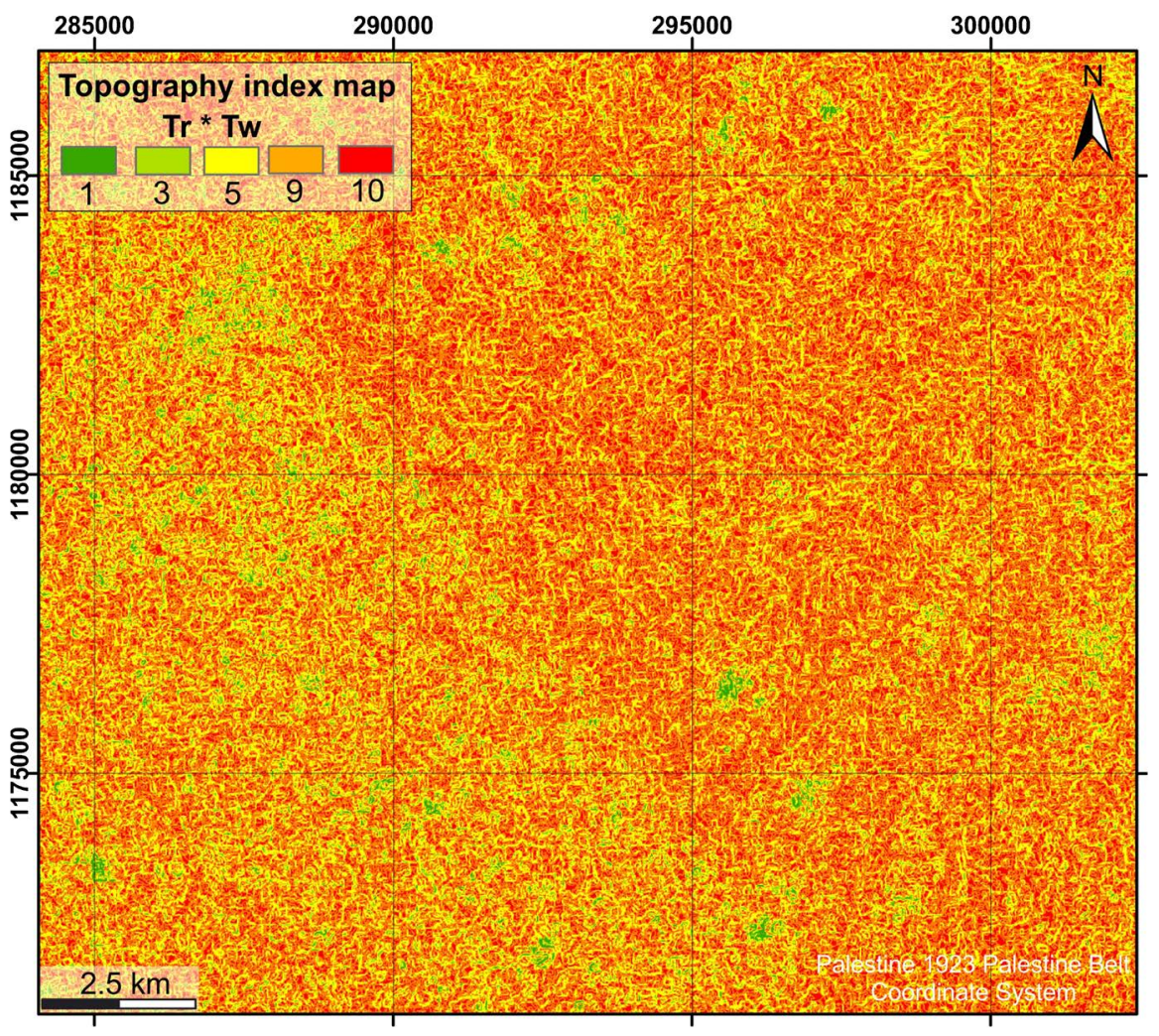

Figure 6. Topography index map $\left(\mathrm{Sr}{ }^{\star} \mathrm{Sw}\right)$ of the Corridor wellfield area. 
bedding planes and hence, play an important role in pollutants moving through the aquifer [27]. The hydraulic conductivity within the study area ranged between $1.2 \mathrm{~m} / \mathrm{d}$ and $6.2 \mathrm{~m} / \mathrm{d}$ [17] [37]. Based on Table 1, the hydraulic conductivity within the study area has a rate of 2 . The hydraulic conductivity index $(\mathrm{Cr}$ * $\mathrm{Cw}$ ) for the study area has a fixed value equal to 6 .

\subsection{DRASTIC Index Vulnerability Map}

The DRASTIC parameter indexes were all obtained through previous calculations. The DRASTIC index equation (Equation (1)) was applied to obtain the final DRASTIC index map. The output DRASTIC vulnerability map shows a range of 109 - 168 (Figure 7).

As shown in Figure 7, within the study area, the DRASTIC vulnerability index ranges between 109 and 168. As a consequence, two vulnerability classes were observed, moderate and high vulnerability classes. The moderate vulnerability class represents $9.9 \%\left(29.40 \mathrm{~km}^{2}\right)$ of the study area, while the high vulnerability class represents $90.1 \%\left(268.35 \mathrm{~km}^{2}\right)$ of the total area of the Corridor wellfield area.

It can be noticed, from the DRASTIC vulnerability map, that soil texture and soil availability plays an essential role in determining the vulnerability class. Aquifer media and impact of vadose zone does not have an impact within the area where both factors are homogeneous, and therefore each parameter has the same rate value throughout the study area.

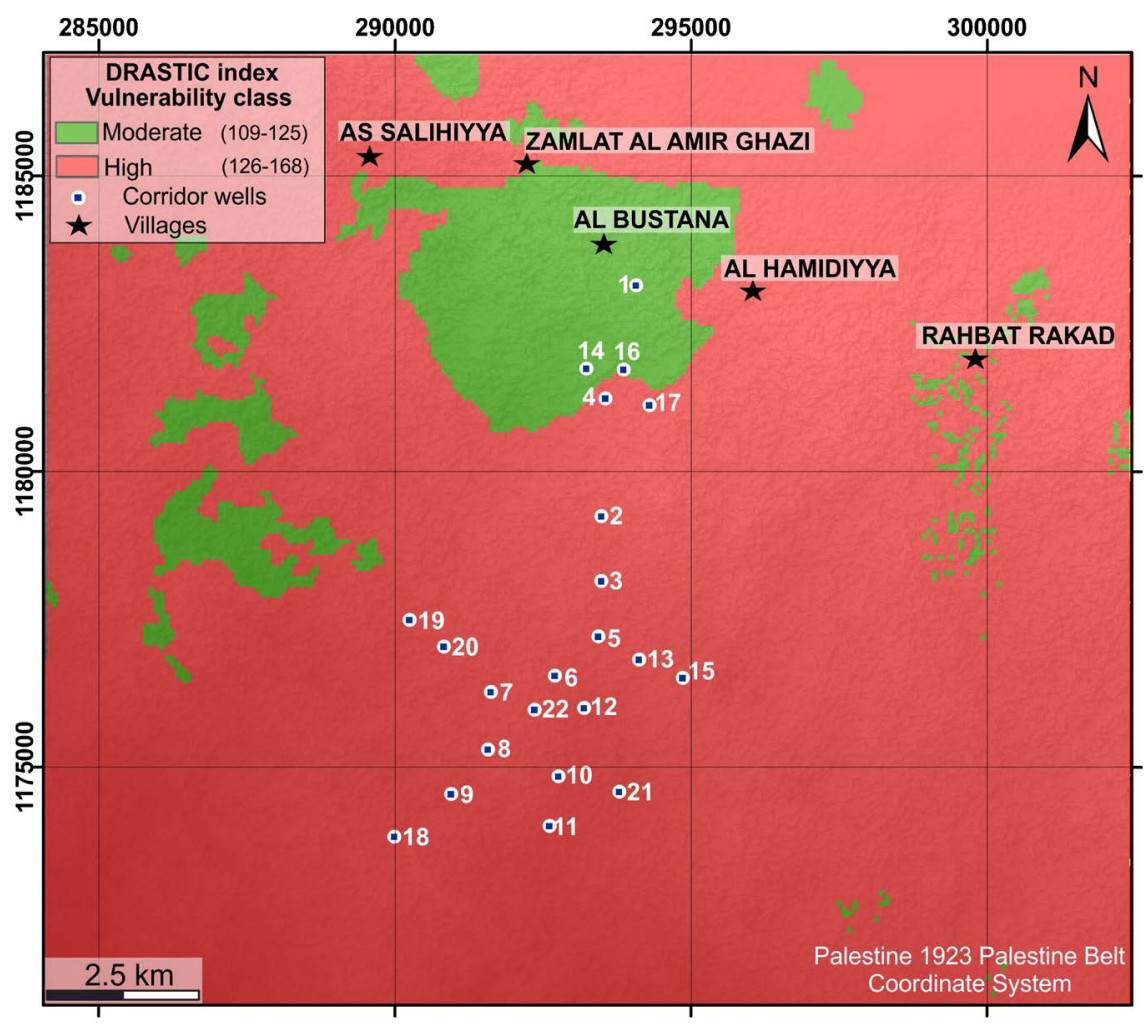

Figure 7. The generic DRASTIC index vulnerability map of the Corridor wellfield area. 


\subsection{Modified DRASTIC Vulnerability Index Map (Risk Map)}

Land-use is a very important key for assessing the land resources, it provides a valuable information about the physiographical characteristics of the surface [38]. A modified DRASTIC map (or risk map) was prepared based on the land-use map of the study area. Three main land use types are identified: urban areas, agricultural areas, and bare rocks areas. According to Table 1, Figure 8 represents the land use index map of the area $\left(\mathrm{Lr}{ }^{\star} \mathrm{Lw}\right)$. By applying equation 3, which combines the DRASTIC index map with the land use index, the modified DRASTIC index map (risk map) for the study area was calculated in Figure 9. The modified DRASTIC vulnerability index (Risk map) ranges between 134 and 198. As a consequence, two risk classes were observed, moderate and high-risk classes. The moderate risk class represents $9.3 \%\left(27.75 \mathrm{~km}^{2}\right)$ of the study area, while the high-risk class represents $90.7 \%\left(270 \mathrm{~km}^{2}\right)$ of the total area of the Corridor wellfield area.

\section{Conclusion}

The main purpose of the study was to carry out an evaluation of the groundwater vulnerability of the Corridor wellfield to pollutants. The study has successfully achieved the aim using the DRASTIC index model and the modified DRASTIC index model that were used in the mapping of the vulnerability of the study area. Based on the study, only two hydrological units are observed within the aquifer system of the study areas, which include the limestone sequences of the Late Cretaceous period and the basaltic rock from the Neogene and Quaternary ages. The study indicated how DRASTIC vulnerability measurement functions to

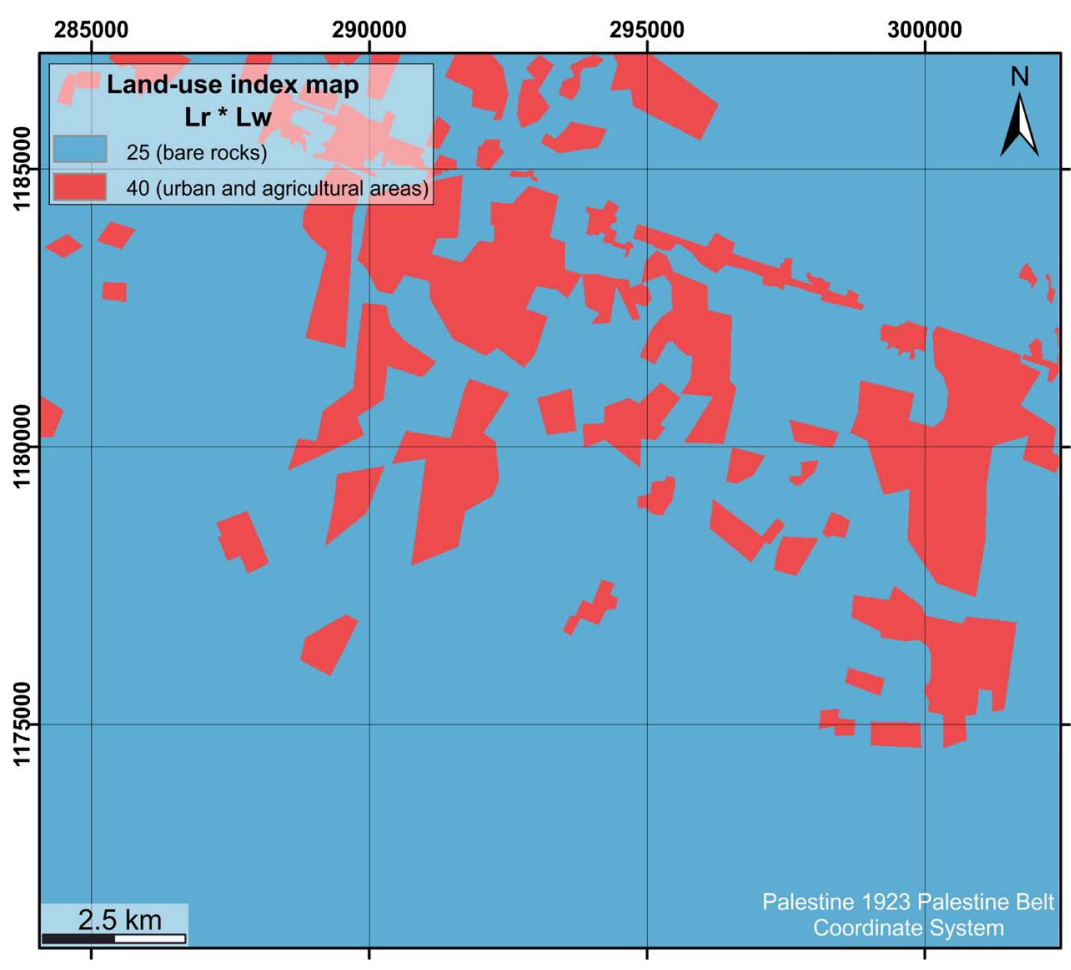

Figure 8. Land-use index map $\left(\mathrm{Lr}^{\star} \mathrm{Lw}\right)$ of the Corridor wellfield area. 


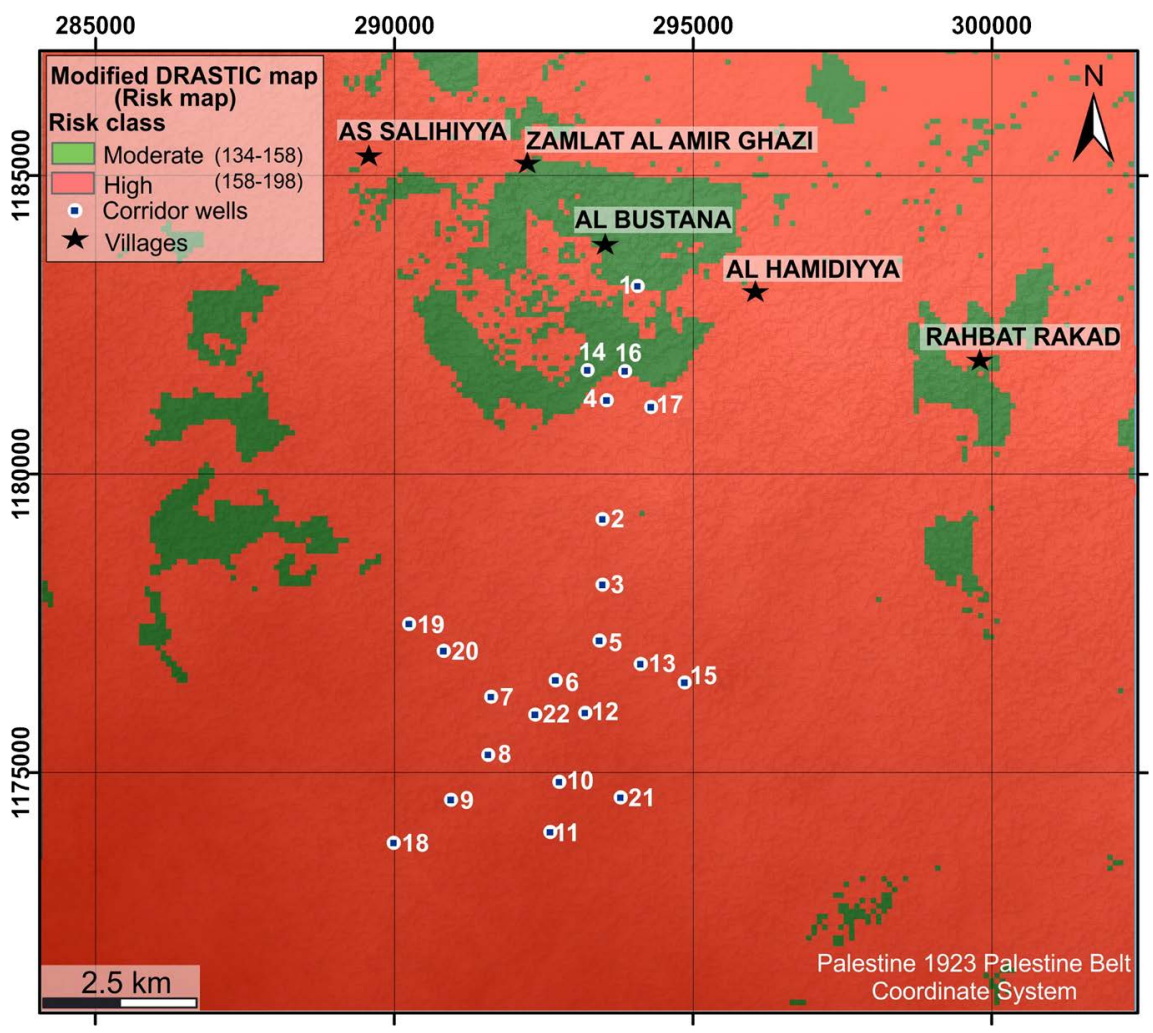

Figure 9. The modified DRASTIC index vulnerability map (Risk map) of the Corridor wellfield area.

map the vulnerability of places using its indexes and the varied datasets required to accomplish the vulnerability testing process. The degradation of groundwater quality is an essential parameter in defining the vulnerability of groundwater to poisonous products. Despite the results depicted that the study area's depth to groundwater is too high; thus, exposing the area to maximum vulnerability due to the impact of the vadose zone media (fractured and vesicular basalt). The topography of the area of study also increases the vulnerability of the area to pollutant runoffs because the area, according to the result has a gently slope. Soil texture similarly plays a role in increasing the amount of vulnerability. Overly, the DRASTIC vulnerability assessment method has provided palpable results in the study. Two vulnerability classes were observed, moderate and high vulnerability classes. The moderate vulnerability class represents $9.9 \%\left(29.40 \mathrm{~km}^{2}\right)$ of the study area, while the high vulnerability class represents $90.1 \%\left(268.35 \mathrm{~km}^{2}\right)$ of the total area of the Corridor wellfield area. The use of the land-use map in combination with the resulted DRASTIC map showed that there are two risk classes: the moderate risk class that represents $9.3 \%\left(27.75 \mathrm{~km}^{2}\right)$, and high-risk class that represents $90.7 \%\left(270 \mathrm{~km}^{2}\right)$. However, testing the validity and credibility of the study results is essential in making a valid conclusion, and this can only be achieved through future studies on the field. Therefore, further investigations should be done in the future to validate the model; this can be done by collecting and analyzing the water quality samples. 


\section{Conflicts of Interest}

The authors declare no conflicts of interest regarding the publication of this paper.

\section{References}

[1] Al Kharadsheh, E., Akroush, S. and Mazahreh, S. (2012) Land Degradation in Jordan-Review of Knowledge Resources. International Center for Agricultural Research in the Dry Areas (ICARDA), OASIS Country Report 1.

[2] MWI (Ministry of Water and Irrigation) (2017) Jordan Water Sector Facts and Figures 2017. Ministry of Water and Irrigation (MWI), Amman.

[3] Margat, J. (1968) Vulnerabilite des nappes d'eau souterraine a la pollution. BRGM-Publication 68 SGL 198 HYD, Orleans.

[4] Abdullahi, U.S. (2009) Evaluation of Models for Assessing Groundwater Pollution in Nigeria. Bayero Journal of Pure and Applied Science, 2, 138-142. https://doi.org/10.4314/bajopas.v2i2.63801

[5] Vrba, J. and Zoporozec, A. (1994) Guidebook on Mapping Groundwater Vulnerability. 16th Edition, International Contributions to Hydrogeology (IAH), Hannover.

[6] Hamdan, I., Margane, A., Ptak, T., Wiegand, B. and Sauter, M. (2016) Groundwater Vulnerability Assessment for the Karst Aquifer of Tanour and Rasoun Springs Catchment Area (NW-Jordan) Using COP and EPIK Intrinsic Methods. Environmental Earth Sciences, 75, 1474. https://doi.org/10.1007/s12665-016-6281-2

[7] Mimi, Z., Mahmoud, N. and Madi, M. (2011) Modified DRASTIC Assessment for Intrinsic Vulnerability Mapping of Karst Aquifers: A Case Study. Environmental Earth Sciences, 66, 447-456. https://doi.org/10.1007/s12665-011-1252-0

[8] Aller, L., Bennett, T., Lehr, J., Petty, R. and Hackett, G. (1987) DRASTIC: A Standardized System for Evaluating Ground Water Pollution Potential Using Hydrogeologic Setting. EPA (Environmental Protection Agency), EPA/600/2-87/035.

[9] Hoelting, B., Haertlé, T., Hohberger, K.-H., Nachtigall, K.H., Villinger, E., Weinzierl, W. and Wrobel, J.-P. (1995) Konzept zur Ermittlung der Schutzfunktion der Grundwasserüberdeckung. Geologisches Jahrbuch Reihe C, Band C, 63, 5-24.

[10] Civita, M. and Demaio, M. (1997) SINTACS: Un systema parametrico per la valutazione e la cartografia della vulnerabilità degli acquiferi all'inquinamento (methodologia e automatizzazione). Pitagora Editrice, Bologna.

[11] Doerfliger, N., Jeannin, P.-Y. and Zwahlen, F. (1999) Water Vulnerability Assessment in Karst Environments: A New Method of Defining Protection Areas Using a Multi-Attribute Approach and GIS Tools (EPIK Method). Environmental Geology Journal, 39, 165-176. https://doi.org/10.1007/s002540050446

[12] Goldscheider, N., Klute, M., Sturm, S. and Hötzl, H. (2000) The PI Method-A GIS-Based Approach to Mapping Groundwater Vulnerability with Special Consideration of Karst Aquifers. Zeitschrift für Angewandte Geologie, 46, 157-166.

[13] Vias, J.M., Andreo, B., Perles, M., Carrasco, F., Vadillo, I. and Jimenez, P. (2006) Proposed Method for Groundwater Vulnerability Mapping in Carbonate (Karstic) Aquifers: The COP Method-Application in Two Pilot Sites in Southern Spain. Hydrogeology Journal, 14, 912-925. https://doi.org/10.1007/s10040-006-0023-6

[14] Goldscheider, N. (2003) The Concept of Groundwater Vulnerability. In: Zwahlen, F., Ed., COST Action 620-Vulnerability and Risk Mapping for the Protection of Carbonate (Karst) Aquifers, Final Report, European Commission, Brussels, 5-9. 
[15] Al Hseinat, M., Al-Rawabdeh, A., Al-Zidaneen, M., Ghanem, H., Al-Taj, M., Diabat, A., Jarrar, G. and Atallah, M. (2020) New Insights for Understanding the Structural Deformation Style of the Strike-Slip Regime along the Wadi Shueib and Amman-Hallabat Structures in Jordan Based on Remote Sensing Data Analysis. Geosciences, 10, 253. https://doi.org/10.3390/geosciences10070253

[16] MWI (Ministry of Water and Irrigation) (2017) Abstraction Data for Corridor Wells. Excel File Format. Amman.

[17] Borgstedt, A., Margane, A., Subah, A., Hajali, Z., Almomani, T., Khalifa, N., Jaber, A. and Hamdan, I. (2007) Delineation of Groundwater Protection Zones for the Corridor Wellfield. German-Jordanian Technical Cooperation Project (BGR-MWI), Amman.

[18] Al Tarawneh, K. (1996) The Geology of the Al Hamidiyya Area, Map Sheet No. 3354-II. NRA Bulletin 35, 33 p., Amman.

[19] Al-Hiyari, A. (2004) Geological Map of Qasr al Hallabat, Map Sheet No. 3254-II. The Hashemite Kingdom of Jordan, Natural Resources Authority, Amman.

[20] Al Tarawneh, K. (2002) The Geology of Umm El Quttein Area, Map Sheet No. 3354-IV. NRA Bulletin 53, Amman, 33p.

[21] Gharaibeh, A. (2005) The Geology of Umm El Jimal Area: Map Sheet No. 3254-1. NRA Bulletin 61, Amman, 32p.

[22] Abed, A.M. (2000) Geology of Jordan. It's Environment and Water; Scientific Series 1; Publication of Association of Jordanian Geologists, Arabic, 571.

[23] Bruckner, F. (2018) Update of Structure Contour Maps of Ajloun and Belqa Groups. German-Jordanian Technical Cooperation Project (BGR-MWI) Improved Groundwater Resources Management in Response to the Syrian Refugee Crisis. Amman.

[24] Altfelder, S., Hamdan, I. and Al-Momani, T. (2008) Building a Groundwater Model for the Corridor Well Field. German-Jordanian Technical Cooperation Project (BGR-MWI), Amman.

[25] Bahls, R., Holzner, K., Al Hyari, M., Al Kurdi, O., Hani, M. and Sawryeh, K. (2018) Groundwater Resources Assessment of the A7/B2 Aquifer in Jordan. German-Jordanian Technical Cooperation Project (BGR-MWI), Amman.

[26] Al-Adamat, R., Foster, I. and Baban, S. (2003) Groundwater Vulnerability and Risk Mapping for the Basaltic Aquifer of the Azraq Basin of Jordan Using GIS, Remote Sensing, and DRASTIC. Applied Geography, 23, 303-324. https://doi.org/10.1016/j.apgeog.2003.08.007

[27] Piscopo, G. (2001) Groundwater Vulnerability Map, Explanatory Notes, Castlereagh Catchment. Centre for Natural Resources, NSW Department of Land and Water Conservation Australia.

[28] Al-Adamat, R. (2002) The Use of Geographical Information Systems (GIS) and Remote Sensing to Investigate Groundwater Quality in the Azraq Basin, Jordan. PhD Thesis, Coventry University, Coventry.

[29] ASF (2020) ALOS PALSAR —Digital Elevation Model (12.5 m Spatial Resolution). https://asf.alaska.edu/data-sets/derived-data-sets/alos-palsar-rtc/alos-palsar-radiom etric-terrain-correction

[30] MOA (Ministry of Agriculture) (1994) Ministry of Agriculture, National Soil Map and Land Use Project-The Soil of Jordan. Level 2: Semi Detailed Studies. Volume 2: Main Report. Hunting Technical Services in Association with Soil Survey and Land Research Centre. Amman. 
[31] MWI and BGR (Ministry of Water and Irrigation; Bundesanstalt für Geowissenschaften und Rohstoffe) (2019) Groundwater Resource Assessment of Jordan 2017. Amman.

[32] Al-Rawabdeh, A., Al-Ansari, N., Al-Taani, A. and Knutsson, S. (2013) A GIS-Based DRASTIC Model for Assessing Aquifer Vulnerability in Amman-Zerqa Groundwater Basin, Jordan. Engineering Journal, 5, 490-504.

https://doi.org/10.4236/eng.2013.55059

[33] Al-Kuisi, M., Mashal, K., Al-Qinna, M., Abu Hamad, A. and Margane, A. (2014) Groundwater Vulnerability and Hazard Mapping in an Arid Region: Case Study, Amman-Zarqa Basin (AZB)-Jordan. Journal of Water Resources and Protection, 6, 297-318. https://doi.org/10.4236/jwarp.2014.64033

[34] Jhariya, D.C., Kumar, T., Pandey, H.K., Kumar, S., Kumar, D., Gautam, A., Baghel, V. and Kishore, N. (2019) Assessment of Groundwater Vulnerability to Pollution by Modified DRASTIC Model and Analytic Hierarchy Process. Environmental Earth Sciences, 78, 610. https://doi.org/10.1007/s12665-019-8608-2

[35] Al-Rawabdeh, A., Al-Ansari, N., Al-Taani, A., Al-Khateeb, F. and Knutsson, S. (2014) Modeling the Risk of Groundwater Contamination Using Modified DRASTIC and GIS in Amman-Zerqa Basin, Jordan. Open Engineering Journal, 4, 264-280. https://doi.org/10.2478/s13531-013-0163-0

[36] Sililo, O.T.N., Saayman, I.C. and Fey, M.V. (2001) Groundwater Vulnerability to Pollution in Urban Catchments. Report to the Water Research Commission, WRC Project No. 1008/1/01. Water Research Commission, ISBN 1868457834. University of Cape Town, Cape Town.

[37] Hobler, M., Margane, A., Almomani, M. and Subah, A. (2001) Groundwater Resources of Northern Jordan, Vol. 4 Contributions to the Hydrogeology of Northern Jordan. Federal Institute for Geosciences and Natural Resources (BGR) and Ministry of Water and Irrigation (MWI), Jordan.

[38] Jawarneh, R. and Biradar, C. (2017) Decadal National Land Cover Database for Jordan at $30 \mathrm{~m}$ Resolution. Arabian Journal of Geosciences, 10, 483.

https://doi.org/10.1007/s12517-017-3266-8 